\title{
DAMPAK TEKNOLOGI PERTANIAN MODERN TERHADAP AKTIVITAS PERTANIAN PADI MASYARAKAT JORONG PIRUKO UTARA KECAMATAN SITIUNG KABUPATEN DHARMASRAYA
}

\author{
M Widodo Saputra ${ }^{1}$, Ratnawilis ${ }^{2}$ \\ Program Studi Pendidikan Geografi \\ Fakultas Ilmu Sosial, Universitas Negeri Padang \\ Emailwidodosaputra263@gmail.com
}

\begin{abstract}
Abstrak
Penelitian ini bertujuan untuk melihat dampak teknologi pertanian modern terhadap produktivitas pertanian padi masyarakatJorong Piruko Utara Kecamatan Sitiung Kabupaten Dharmasraya. Jenis penelitian ini menggunakan jenis penelitian Mixed Method. Hasil produktivitas pertanian padi petani di Jorong Piruko Utara sebelum menggunakan teknologi pertanian modern sebesar Rp.10.540.000 sedangkan sesudah menggunakan teknologi pertanian modern hasil produktivitasnya meningkat menjadi Rp.12.490.000. jadi, diperoleh selisih Rp.1.950.000.
\end{abstract}

Kata Kunci : Produktivitas pertanian padi

Abstract

This research aim to see the impact of the agriculture technology towards the productivity of societes paddy field in Jorong Piruko, Subdistrict Sitiung, Dharmasraya Regency. The type of this research used mixed method. The amount of society paddy field productivity in Jorong Piruko Utara before using modern agriculture technology is Rp.10.540.000 after using modern agriculture technology the amount of paddy field productivity increased to Rp.12.490.000. so, there is a difference Rp.1.950.000.

Keywords: Productivity of societes paddy

\footnotetext{
${ }^{1}$ Mahasiswa Program Studi Pendidikan Geografi

${ }^{2}$ DosenJurusanGeografiFakultasIlmuSosialUniversitas Negeri Padang dengan Pembimbing I

Dra. Yurni Suasti, M.Sidan Pembimbing II Ahyuni, ST M.Si
} 


\section{PENDAHULUAN}

Indonesia merupakan negara
agraris yang sebagian besar penduduknya bermata pencaharian sebagai petani. Di Indonesia sektor pertanian memegang peranan penting perekonomian nasional. Hampir di setiap wilayah yang berada di Indonesia memiliki pertanian, terutama pertanian padi sawah yang menjadi bahan kebutuhan pokok masyarakat Indonesia.

Sektor pertanian merupakan salah satu sektor yang menyediakan bahan pangan bagi setiap penduduk di negara berkembang khususnya Indonesia, serta memberikan lapangan kerja bagi hampir seluruh angkatan kerja yang ada. Pertanian padi sawah merupakan produk unggulan bagi sebagian besar wilayah yang ada di Indonesia.

Pertanian padi sawah ialah salah satu tanaman pangan yang menjadi bahan pokok yang sangat penting bagi setiap masyarakat di Indonesia, meskipun terkadang hasil pertanian padi di Indonesia belum mencukupi permintaan yang ada, sehingga masih mengimpor dari negara-negara tetangga seperti Thailand yang menjadi lumbung padi Asia Tenggara. Keadaan ini disebabkan karena belum maksimalnya para petani indonesia dalam pengolahan pertanian, serta teknologi yang digunakan masih menggunakan alat-alat tradisional sehingga menyebabkan hasil produksi serta waktu yang dibutuhkan dalam mengolah lahan pertanian belum maksimal.

Petani merupakan orang yang bergerak pada bidang pertanian. Berbicara mengenai petani, banyak kalangan berpendapat bahwa masyarakat yang bekerja pada sektor pertanian ialah masyarakat menengah kebawah yang berprofesi sebagai petani untuk memenuhi kebutuhan hidupnya. Petani yang ada di Indonesia sebagian besar dikategorikan petani miskin, ini dilihat dari cara pengolahan pertanian yang masih menggunakan alat-alat tradisional yang membutuhkan waktu yang sangat lama dalam pengolahan pertanian, namun tidak semua petani yang ada di Indonesia ini masih menggunakan alat-alat tradisional untuk mengolah lahan pertaniannya, semakin berkembangnya ilmu teknologi secara global membuat dunia pertanian menjadi suatu wadah bagi perusahaanperusahaan pembuat teknologi berlomba-lomba untuk menciptakan produk pertanian yang berupa mesinmesin canggih yang dapat digunakan oleh petani dalam menggarap lahan pertaniannya. Dengan adanya teknologi pertanian modern ini membuat para petani lebih mudah dalam mengolah lahan dan lebih menghemat waktu serta biaya yang dikeluarkan.

Teknologi pertanian modern ini merupakan teknologi pertanian yang digunakan untuk mempermudah dan mempercepat serta meningkatkan hasil produksi pertanian. Teknologi pertanian modern ini berupa mesin-mesin yang diciptakan untuk pengolahan serta pengambilan hasil produksi misalnya pada bidang pertanian padi dalam pengolahan tanah petani sudah menggunakan mesin (rotari), bibit yang digunakan bibit unggul, cara penanaman dengan menggunakan mesin tanam padi, proses panen sudah menggunakan mesin (kombin), sistem 
perekrutan tenaga kerja dilihat dari hasil kerja, pencarian tenaga kerja langsung pemilik, dan sistem pembagian hasil berupa uang atau hasil padi yang dipanen (bayar langsung setelah bekerja).adanya teknologi pertanian modern ini memberikan perubahan bagi kehidupan di daerah pedesaan. Terutama pada petani di Jorong Piruko Utara Kecamatan Sitiung Kabupaten Dharmasraya yang mempunyai jumlah petani sebanyak 124 orang terdiri atas 5 kelompok Hamparan pertanian dengan jumlah lahan $\pm 112,25 \mathrm{Ha}$.

Petani yang ada di Jorong Piruko Utara Kecamatan Sitiung Kabupaten Dharmasraya dulunya masih sering menggunakan alat tradisional, seperti cangkul, sabit, bajak kecil dan lain sebagainya, untuk melakukan aktivitas pertanian, maka tidak lagi pada zaman sekarang. Masyarakat desa mulai beralih untuk menggunakan teknologi pertanian yang lebih modern, seperti (rotari) untuk menggemburkan atau mengolah tanah, (kombin) untuk memanen padi, mesin tanam yang sudah menggantikan tenaga manusia dan lain sebagainya.

Adanya perubahan pada bidang teknologi pertanian ini, masyarakat Jorong Piruko Utara terbantu dalam berbagai hal seperti, pengolahan lahan maupun pemanenanan hasil produksi pertanian, karena dengan teknologi pertanian ini dapat menghemat biaya produksi, menghemat waktu pengolahan lahan, mengurangi pekerja, dan mempercepat serta memudahkan pekerjaan petani,sehingga membuat petani semangat untuk menggarap lahannya dalam bidang pertanian padi sawah khususnya pada masyarakat Jorong Piruko Utara. Namun bagaimana halnya dengan para pekerja pertanian yang tidak memiliki lahan dan menggantungkan hidupnya dengan bekerja pada pemilik lahan pertanian, atau para anggota gotong royong yang telah terbentuk selama ini pada masyarakat Jorong Piruko Utara yang menggunakan kemampuannya untuk mengolah, menanam, hingga memanen padi. Kebanyakan anggotanya mempunyai lahan namun dengan adanya gotong royong ini sedikit banyaknya membantu para anggotanya untuk memenuhi kebutuhan dapur mereka karena kebanyakan anggota gotong royong ini adalah ibu-ibu yang hanya memiliki keahlian pada bidang pertanian. Serta dengan adanya gotong royong ini interaksi antar masyarakat selalu terjaga dengan baik serta meningkatkan komunikasi diantara mereka.

Meskipun adanya teknologi pertanian modern ini memberikan berbagai dampak positif, baik dari segi waktu, biaya, tenaga kerja yang diperlukan mulai dari pengolahan hingga pemanenan. Akan tetapi untuk hasil produksi padi sebagian masyarakat Jorong Piruko Utara belum merasakan dampak yang memuaskan.

Teknologi pertanian modern ini dibeberapa wilayah mungkin masih belum sesuai untuk diterapkan secara keseluruhan, karena masih harus mempertimbangkan beberapa faktor, terutama faktor sosial, kondisi alam, tenaga ahli yang mengoperasikan peralatan, serta pengetahuan masyarakat tentang alat teknologi pertanian modern. 
Sehingga ini hanya menguntungkan pemilik mesin semata jika tidak secara bijak dalam penggunaanya. Maka dari itu pertanian padi yang ada di Jorong Piruko Utara haruslah disesuaikan dengan karakteristik petaninya sehingga tidak berdampak negatif terhadap petani yang dapat menyebabkan kesenjangan sosial.

Pertanian adalah suatu jenis kegiatan produksi yang berlandaskan proses pertumbuhan dari tanaman dan hewan. Semua itu merupakn hal yang penting, secara garis besar pengertin pertanian dapat diringkas menjadi proses produksi, petani atau pengusaha, tanah tempat usaha, usaha pertanian (farm busines). Awal kegiatan pertanian terjadi ketika manusia mulai mengambil peranan dalam proses kegiatan tanaman dan hewan serta pengaturannya untuk memenuhi kebutuhan. Tingkat kemajuan pertanian mulai darai pengumpul dann pemburu, pertanian primitif, pertanian tradisonal sampai dengan pertanian modern. Dengan bertambahnya jumlah penduduk akan mempercepat habisnya pangan yang ada di alam sekitar mereka. Untuk memenuhi kebutuhannya mereka atau petani berpindah-pindah tempat. Selanjutnya perpindahan tersebut tidak lagi dapat memecahkan masalah karena jumlah manusia sudah tidak seimbang lagi dengan pangan secara alami. Akhirnya, petani mulai berfikir untuk mengetahui mengaapa masalah itu timbul serta berusaha memecahkannya walaupun dengan cara atau tindakan yang menurut ukuran sekarang sangat sederhana. ( Soetriono, dalam jurnal Sudy, 2015).
Nasoetion (2003) menjelaskan bahwa usaha pertanian pada dasarnya berstandar pada kegiatan menyadap energi surya agar menjadi energi kimia melalui proses fotosintesis Mangunwidjaja, (2005). Hasil fotosintesis ini kemudian menjadi bagian tumbuhan dan hewan yang dapat dijadikan manusia sebagai bahan pangan, sandang dan papan, sumber energi, serta bahan baku industri.

Mosher (1985) Membagi pertanian dalam dua golongan, yaitu pertanian primitif dan pertanian modern. Pertanian primitif diartikan sebagai petani yang bekerja mengikut metode-metode yang berasal dari orangorang tua dan tidak menerima pemberitahuan (inovasi). Mereka yang mengharapkan bantuan alam untuk mengolah pertaniannya. Sedangkan pertanian modern diartikan sebagai menguasai pertumbuhan tanaman dan aktif mencari metode-metode baru serta dapat menerima pembaruan atau inovasi dalam bidang pertanian. Petani yang seperti ini dapat berkembang dalam rangka menunjang ekonomi baik dibidang pertanian maupun di bidangbidang lainnya. Sudy (2015).

Teknologi hendaknya memiliki syarat-syarat sebagai berikut : 1). Teknologi baru hendaknya lebih uggul dari sebelumnya. 2). Mudah digunakan, dan 3). Tidak memberikan resiko yang besar jika diterapkan. Mosher (1985), teknologi merupakan salah satu syarat mutlak pembangunan pertanian. Sedangkan untuk mengintroduksi suatu teknologi baru pada suatu usaha tani menurut Fadholi (1991) ada empat faktor yag perlu diperhatikan yaitu (1). 
Secara teknis dapat dilaksanakan, (2). Secara ekonomi menguntungkan, (3). Secara sosial dapat diterima dan (4). Sesuai dengan peraturan pemerintah.

Teknologi atau ide baru akan diterima oleh petani jika: (a). Memberi keuntungan ekonomi bila teknologi tersebut diterapkan (profitability). (b). Teknologi tersebut sesuai dengan lingkungan budaya setempat (cultural compability). (c). Kesesuaian dengan lingkungan fisik (physical compability). (d). Teknologi tersebut memiliki kemudahan jika diterapkan. (e). Penghematan tenaga kerja dan waktu dan (f). Tidak memerlukan biaya yag besar jika teknologi tersebut diterapkan (Mardikato, 1993 dalam Sudy, 2015).

Teknologi pertanian yaitu penerapan dari ilmu-ilmu teknik kepada kegiatan pertanian. Secara lengkap dari aspek ranah keilmuan, teknologi pertanian dapat diuraikan sebagai suatu penerapan prinsip-prinsip matematika dan sains alam dalam rangka pendayagunaan secara ekonomis sumber daya pertanian dan sumber daya alam untuk kepentingan kesejahteraan manusia.

Teknologi hendaknya memiliki syarat-syarat sebagai berikut : (1). Teknologi baru hendaknya lebih unggul dari sebelumnya, (2). Mudah digunakan dan (3). Tidak memberikan resiko yang besar jika diterapkan. Sedangkan unruk mengintroduksi suatu teknologi baru pada usaha tani menurut Fadholi (1991), ada empat faktor yang perlu diperhatikan yaitu, (1). Secara teknis dapat dilaksanakan, (2). Secara ekonomi menguntungkan. (3). Secara sosial dapat diterima dan (4). Sesuai dengan peraturan pemerintah.

Suatu teknologi atau ide baru dapat diterima petani jika (a). Memberi keuntungan ekonomi bila teknologi itu diterapkan, (b). Teknologi tersebut sesuai dengan lingkungan budaya setempat, (c). Sesuai dengan lingkungan fisik, (d). Teknologi tersebut memiliki kemudahan jika diterapkan, (e). Penghematan tenagakerja dan waktu (f). Tidak memerlukan biaya yang besar jika teknologi tersebut diterapkan (Mardikanto, 1993 dalam Sudy, 2015).

\section{METODE PENELITIAN}

Kegiatan penelitian ini dilaksanakan di Jorong Piruko Utara Kecamatan Sitiung Kabupaten Dharmasraya. Sesuai dengan tujuannya, penelitian ini merupakan penelitian yang menggunakan metode gabungan (mixed method) dalam bentuk sekuensial yakni peneliti pada tahap pertama menggunakan penelitian kuantitatif, lalu dilanjutkan dengan penelitian kualitatif, yang menjadi sampel penelitian ini adalah petani di Jorong Piruko Utara.

Berdasarkan sumber data yang akan dikumpulkan maka jenis data tergolong data sekunder dan primer. Dalam penelitian ini adalah produktivitas pertanian padi sebelum dan sesudah menggunakan teknologi pertanian modern. Sedangkan data primer perspektif masyarakat terhadap teknologi pertanian modern.

Teknik pengumpulan data dilakukan untuk memperoleh data berkenaan dengan produktivitas pertanian padi dan perspektif 
masyarakat terhadap teknologi pertanian modern. Instrumen yang digunakan dalam penelitian ini adalah angket dan pedoman wawancara.

\section{HASIL DAN PEMBAHASAN}

Teknologi pertanian modern yang diaplikasikan di Jorong Piruko Utara mebawa dampak terhadap produktivitas pertanian padi maupun sosial masyarakat Jorong Piruko Utara. Data yang diperoleh dari Badan Penyuluhan Pertanian (BPP) pada tahun 2014 mencatat produktifitas pertanian padi di Jorong Piruko Utara Kecamatan Sitiung Kabupaten Dharmasraya selama satu kali panen dengan luas lahan $1 \mathrm{Ha}$ sebelum menggunakan teknologi pertanian modern disajikan pada tabel 1 berikut:

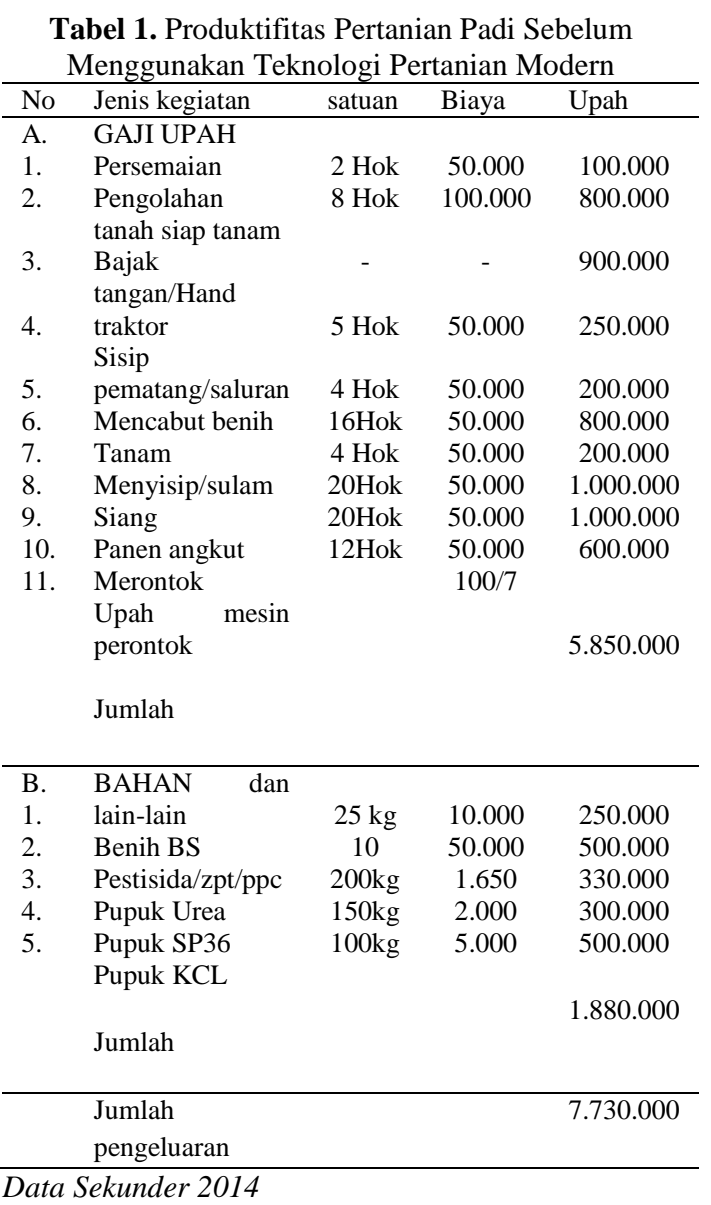

Hasil pertanian padi dalam $1 \mathrm{Ha}$ lahan menghasilkan 87 karung dan setiap karung rata-rata beratnya mencapai $50 \mathrm{~kg}$, maka beratnya sekitar $4.350 \mathrm{~kg}$. Harga padi basah $1 \mathrm{~kg}$ Rp.4.200 dengan demikian hasil kotor panen padi diperoleh Rp.18.270.000. Hasil tersebut dikurangi dengan modal awal Rp.7.730.000. maka diperoleh untung Rp.10.540.000 setiap kali panen sebelum menggunakan teknologi pertanian modern.

Data yang diperoleh dari penelitian dilapangan tentang produktifitas pertanian padi yang sudah menggunakan teknologi pertanian modern dijabarkan pada tabel 2 berikut:

Tabel 2. Produktifitas Pertanian Padi Sesudah Menggunakan Teknologi Pertanian Modern

\begin{tabular}{|c|c|c|c|c|}
\hline No & Jenis kegiatan & Satuan & Biaya & Upah \\
\hline A. & GAJI UPAH & & & \\
\hline 1. & Persemaian & 2 Hok & 50.000 & 100.000 \\
\hline 2. & $\begin{array}{l}\text { Pengolahan tanah } \\
\text { siap tanam }\end{array}$ & 4 Hok & 100.000 & 400.000 \\
\hline 3. & Bajak Rotari & & & 900.000 \\
\hline 4. & $\begin{array}{l}\text { Sisip } \\
\text { pematang/saluran }\end{array}$ & - & - & - \\
\hline 5. & Mencabut benih & 2 Hok & 50.000 & 100.000 \\
\hline 6. & Mesin Tanam & & & 750.000 \\
\hline 7. & Menyisip & 5 Hok & 50.000 & 250.000 \\
\hline 8. & Siang & 20 & 50.000 & 1.000 .000 \\
\hline 9. & Panen angkut & Hok & 100.000 & 400.000 \\
\hline 10. & Merontok & 4 Hok & - & - \\
\hline \multirow[t]{2}{*}{11.} & $\begin{array}{l}\text { Upah mesin } \\
\text { perontok }\end{array}$ & - & $100 / 12$ & \\
\hline & Jumlah & & & 3.900 .000 \\
\hline $\begin{array}{l}\text { B. } \\
1 .\end{array}$ & $\begin{array}{l}\text { BAHAN dan lain- } \\
\text { lain }\end{array}$ & $25 \mathrm{~kg}$ & 10.000 & 250.000 \\
\hline 2. & Benih BS & 10 & 50.000 & 500.000 \\
\hline 3. & Pestisida/zpt/ppc & $200 \mathrm{~kg}$ & 1.650 & 330.000 \\
\hline 4. & Pupuk Urea & $150 \mathrm{~kg}$ & 2.000 & 300.000 \\
\hline \multirow[t]{4}{*}{5.} & Pupuk SP36 & $100 \mathrm{~kg}$ & 5.000 & 500.000 \\
\hline & Pupuk KCL & & & \\
\hline & Jumlah & & & \\
\hline & & & & 5.780 .000 \\
\hline
\end{tabular}

Hasil pertanian padi dalam $1 \mathrm{Ha}$ lahan menghasilkan 87 karung dan setiap karung rata-rata beratnya mencapai 50kg. Harga padi basah $1 \mathrm{~kg}$ 
Rp.4.200 dengan demikian hasil kotor panen padi diperoleh Rp.18.270.000. Hasil tersebut dikurangi dengan modal awal Rp.5.780.000. maka diperoleh untung Rp.12.490.000 setiap kali panen sesudah menggunakan teknologi pertanian modern

Data yang diperoleh dari Badan Penyuluhan Pertanian Nagari (BPP) dan penelitian lapangan tentang produktifitas pertanian padi diperoleh hasil yang berbeda antara sebelum menggunakan teknologi pertanian dan sesudah menggunakan teknologi pertanian modern, dari sebelum menggunakan teknologi pertanian hasil produktifitas pertanian padi sebanyak Rp.10.540.000 sedangkan sesudah menggunakan teknologi petani mendapatkan untung Rp.12.490.000. Jadi, dari data tersebut diperoleh selisih Rp.1.950.000.

Hasil dilapangan tersebut sesuai dengan teori yang dikemukakan oleh Fadholi (1991) yaitu, untuk mengintroduksi suatu teknologi baru pada usaha tani, ada empat faktor yang perlu diperhatikan yaitu , (1). Secara teknis dapat dilaksanakan, (2). Secara ekonomi menguntungkan. (3). Secara sosial dapat diterima dan (4). Sesuai dengan peraturan pemerintah.

Teknologi pertanian modern yang ada di Jorong Piruko Utara ini secara teknis dapat dilaksanakan, teknologi pertanian modern ini sesuai jika diaplikasikan di daerah Jorong Piruko Utara ini karena struktur lahannya yang datar dan jarang sekali lahan rawa di daerah ini, selain itu secara ekonomi menguntungkan, terbukti dari hasil penelitian dilapangan didapatkan keuntungan Rp.10.540.000 sebelum menggunakan teknologi pertanian modern sedangkan dengan menggunakan teknologi pertanian modern keuntungan petani menjadi Rp.12.490.000 lebih meningkat jika dibandingkan dengan sebelum menggunakan teknologi pertanian modern. Secara sosial dapat diterima, petani di Jorong Piruko Utara sangat setuju dengan adanya teknologi pertaniann modern ini dapat dilihat dari wawancara yang dilakukan peneliti terhadap beberapa informan yang menyatakan mereka sangat setuju dengan adanya teknologi pertanian modern ini karena dengan adanya alat mereka bisa dikatakan petani modern dan teknologi tersebut membantu meringankan petani dan banyak lagi keunggulan yang didapatkan dari teknologi pertanian modern tersebut.

Hasil penelitian melalui penyebaran angket kepada masyarakat Sesuai dengan analisis regresion dalam SPSS 2.0 for windows maka didapatkan hasil $6.1 \%$, artinya teknologi pertanian modern berdampak terhadap produktifitas pertanian padi masyarakat Jorong Piruko Utara dengan dampak yang kecil. Hal tersebut disebabkan karena teknologi pertanian modern ini tidak mempengaruhi hasil panen padi pada masyarakat Jorong Piruko Utara, namun dampak teknologi pertanian ini mengurangi biaya yang dikeluarkan oleh petani atau mengurangi modal, mempercepat pekerjaan petani, menghemat waktu, dan mempercepat jarak tanam. Sedangkan untuk hasil itu sendiri dipengaruhi oleh bibit yang digunakan oleh petani, perawatan yang 
dilakukan oleh petani, berapa banyak pupuk yang digunakan, cuaca serta hama yang menyerang pertanian padi itu sendiri.

Untuk perspektif masyarakat
terhadap teknologi
modernHasil dari wawancara yang telah dilakukan kepada para responden maka perspektif masyarakat terhadap teknologi pertanian modern ini sangat membantu pekerjaan petani dalam berbagai hal misalnya dari segi waktu yang petani butuhkan untuk mengolah hingga memanen padi mereka sangatlah cepat, jarak tanam dan panen mereka yang menjadi singkat setelah adanya teknologi pertanian modern ini, tenaga yang mereka butuhkan lebih sedikit sehingga mengurangi biaya yang mereka keluarkan.

Dari ketiga teknologi pertanian modern yang ada di Jorong Piruko Utara yakni, mesin rotari, mesin tanam, mesin kombin, dari ketiganya petani lebih banyak menggunakan mesin rotari untuk mengolah dan menggemburkan tanah mereka dan mesin kombin untuk memanen hasil pertanian mereka sedangkan untuk mesin tanam itu sendiri petani yang ada di Jorong Piruko Utara ini jarang menggunakannya karena bagi mereka masih terlalu rumit dalam mengaplikasikan alat tersebut kelahan mereka karena kebanyakan petani belum bisa membuat semaian mereka sendiri karena jika menggunakan mesin tanam mereka harus membuat persemeaian khusus, Selain itu keterbatasan alat juga membuat petani lebih memilih menggunakan sistem tabela (tabur), ngicir, ataupun tanam manual dengan menggunakan jasa ibu-ibu gotong royong.

Untuk pengaruh alat terhadap lahan persawahan mereka kebanyakan petani mengatakan teknologi pertanian modern memang mempengaruhi lahan mereka yakni lahan pertanian mereka semakin dalam namun alat yang dimaksudkan oleh petani yakni mesin rotari, karena mesin ini mempunyai berat lebih kurang 3 ton dan mempunyai ban yang cukup besar sehingga membuat lahan pertanian semakin dalam jika terus menerus mengolah lahan dengan mesin rotari ini, namun petani dapat mengurangi resikonya dengan cara $2 \mathrm{x}$ menggunakan mesin rotari dan $1 \mathrm{x}$ menggunakan bajak kecil atau dengan cara mengikuti program pemerintah $2 \mathrm{x}$ tanam padi dan $1 \mathrm{x}$ tanam palawija agar lahan mereka menjadi keras lagi dan mengembalikan unsur hara dalam tanah.

Merujuk pada pendapat (Mardikato, 1993 dalam Sudy, 2015), teknologi atau ide baru diterima oleh petani jika: (a). Memberi keuntungan ekonomi bila teknologi tersebut diterapkan. (b). Teknologi tersebut sesuai dengan lingkungan budaya setempat (cultural compability). (c). Kesesuain dengan lingkungan fisik. (d). Teknologi tersebut memiliki kemudahan jika diterapkan. (e). Penghematan tenaga kerja dan waktu. (f). Tidak memerlukan biaya yang besar jika teknologi tersebut diterapkan.

Berdasarkan pendapat responden di Jorong Piruko Utara teknologi pertanian yang ada membawa dampak keuntungan ekonomi saat penerapannya, karena bagi petani dengan adanya mesin mereka lebih 
menghemat biaya pengeluaran, karena tenaga yang dibutuhkan petani untuk membantu mengolah hingga pemanenan berkurang.

Teknologi tersebut sesuai dengan lingkungan budaya setempat, petani di Jorong Piruko Utara ini berpendapat jika teknologi yang ada tidak pernah membuat pudarnya hubungan kekerabatan maupun persaudaraan, karena meskipun mereka menggunakan teknologi mereka juga masih membutuhkan tenaga saudara maupun tenaga orang lain dalam pertanian mereka, misalnya dalam penanaman padi mereka masih menggunakan tenaga orang lain untuk menyisip tanaman mereka ataupun dalam perawatan seperti menyiang tanaman dari gulma mereka juga masih membutuhkan anggota gotong royong serta dalam pemanenan padi mereka masih menggunakan tenaga kerabat untuk membantu mengangkat padi yang sudah siap dipanen dari sawah kerumah mereka dan sistem tersebut masih secara bergantian petani lakukan sesama kerabat mereka.

Selain itu pemerintah ikut andil dalam menjaga sistem budaya, menjaga kondisi tanah pertanian petani, serta memberi lapangan kerja kepada masyarakat dengan cara setelah 2 musim pertanian padi pemerintah akan melakukan penutupan perairan induk yang mengaliri sawah petani dengan alasan perbaikan perairan dalam kurun waktu 2-3 bulan secara bertahap agar petani dapat menanam palawija dan disini pemerintah memberikan bibit palawija kepada petani dan membeli kembali hasil palawija yang petani panen seperti jagung, sehingga dengan cara seperti ini siitem gotong royong yang ada di Jorong Piruko Utara ini tidak hilang begitu saja. Meskipun tidak semua kelompok tani melakukan rotasi tanaman ini namun secara bertahap petani yang ada di Jorong Piruko Utara sekarang mulai meningkat melakukan kebijakan yang dilakukan pemerintah ini karena mereka sudah dapat memahami dengan cara ini tanah mereka akan kembali subur dan hama yang ada di sawah mereka akan berkurang.

Kesesuaian dengan lingkungan fisik, teknologi pertanian modern yang ada sekarang ini memang sesuai jika diterapkan di Jorong Piruko Utara ini karena sawah yang ada disini daerahnya datar dan tidak ada atau sangat sedikit daerah persawahan yang tergolong rawa sehingga teknologi ini sangat sesuai jika diaplikasikan di Jorong Piruko Utara ini.

Teknologi tersebut memiliki kemudahan jika diterapkan karena kini masyarakat dapat menggunakan teknologi pertanian ini secara mudah hanya dengan melihat masyarakat dapat mengaplikasikan disawah mereka misalnya pada mesin tanam dan rotari sudah banyak petani yang dapat menggunakan alat ini karena alat ini dimiliki oleh kelompok pertanian mereka yang mereka dapatkan dari banuan pemerintah daerah di Kabupaten Dharmasraya sedangkan untuk alat kombin masih dimiliki oleh pribadi dan pemilik tersebutlah yang bisa mengaplikasikannya di sawah petani.

Teknologi pertanian modern yang ada di Jorong Piruko Utara ini sangat 
meghemat tenaga kerja dan waktu yang dibutuhkan petani untuk mengolah hingga pemanenan, misalnya dulu sebelum menggunakan rotari masyarakat membutuhkan tenaga kerja 3-5 orang untuk mengolah tanah mereka, kini petani hanya membutuhkan 1 operator dan pemilik lahan sendiri untuk memperbaiki pematang sawah mereka dengan waktu $1 / 2$ hari dalam 1 hektar untuk pembajakan lahan mereka, untuk mesin tanam dulu masyarakat menggunakan tenaga $10-15$ orang pekerja untuk penanaman kini hanya membutuhkan 1 operator mesin tanam dan 5 orang pekerja untuk mengambil benih dan menyisip tanaman, dan untuk mesin rotari petani hanya membutuhkan 2-3 operator tergantung mesin yang digunakan dan 3 orang tenaga untuk mengangkut hasil pertanian mereka dengan waktu hitungan jam saja tergantungan lahan pertanian petani, sedangkan dulu sebelum ada mesin petani membutuhkan 15-25 orang pekerja dengan waktu 2-3 hari dalam memanen hasil pertanian mereka.

Tidak memerlukan biaya yang besar jika teknologi tersebut diterapkan, menurut pendapat informan yang telah dilakukan wawancara petani tidak merasa biaya yang dikeluarkan sangatlah mahal karena biaya yang dikeluarkan petani untuk penggunaan teknologi ini masih terjangkau oleh petani itu sendiri dan sesuai dengan kinerja yang mesin lakukan untuk pertanian mereka.

\section{PENUTUP}

\section{A. Kesimpulan}

Berdasarkan hasil penelitian dilapangan mengenai dampak teknologi pertanian modern terhadap aktivitas pertanian padi masyarakat Jorong Piruko Utara Kecamatan Sitiung Kabupaten Dharmasraya dapat disimpulkan sebagai berikut.

1. Dampak teknologi pertanian modern terhadap produktivitas pertanian padi masyarakat Jorong Piruko Utara yakni pengurangan modal oleh petani sehingga petani mendapat keuntungan Rp.1.950.000 yang didapat dari selisih sebelum dan sesudah menggunakan teknologi pertanian modern, Sedangkan dari hasil penelitian didapatkan hasil $6,1 \%$ dampak teknologi pertanian modern yang mempengaruhi produktivitas pertanian padi, kecil sekali dampak teknologi pertanian modern ini terhadap produktivitas pertanian padi, karena faktor yang mempengaruhi produktivitas itu sendiri ialah bibit, pupuk, perawatan, serta cuaca.

2. Perspektif atau pendapat petani terhadap teknologi pertanian modern di Jorong Piruko utara ini yakni memberi keuntungan ekonomi bagi petani karena mereka hemat dalam penggunaan tenaga dan waktu sehingga mengurangi biaya yang mereka keluarkan. Teknologi pertanian modern ini juga sesuai dengan budaya masyarakat tani di Jorong Piruko Utara ini karena meskipun menggunakan teknologi pertaanian modern ini sistem kekerabatan ataupun saudara masih tetap terjaga 
dengan baik, para anggota gotong royong juga masih tetap bisa bekerja. Teknologi pertanian modern ini sesuai dengan lingkungan fisik di Jorong Piruko Utara karena lahan persawahan yang ada disini daerahnya datar, pembuangan air yang mudah, lahan kering dan sedikit sekali daerah persawahan yang tergolong rawa. Teknologi pertanian modern ini mudah diterapkan karena setiap kelompok hamparan pertanian sudah memiliki masing-massing mesin tanam dan mesin rotari sehingga petani mudah meminjamnya dan operator pun banyak karena sudah banyak petani yang dapat menjalankan alat pertanian ini. Penghematan tenaga kerja dan waktu, dengan adanya teknologi pertanian modern ini jarak tanam lebih cepat serta mengolah hingga memanen lebih cepat selesai serta tenaga yang dibutuhkan petani untuk mengolah hingga memanen sangat sedikit sehingga mengurangi biaya yang dikeluarkan petani. Tidak memerlukan biaya yang besar jika teknologi pertanian modern ini diterapkan karena masih terjangkau bagi petani serta sesuai dengan kinerja alat yang cepat dan tenaga yang sedikit.

\section{B. Saran}

Adapun saran yang bisa penulis sampaikan untuk beberapa pihak adalah sebagai berikut:

1. Bagi pemerintah hendaknya memberi bantuan alat pertanian berupa mesin kombin kepada kelompok pertanian, karena masyarakat ingin memiliki secara bersama agar biaya yang mereka keluarkan untuk lebih sedikit lagi seperti halnya bantuan mesin rotari maupun mesin tanam.

2. Bagi pemerintah hendaknya membantu petani untuk masalah pembangunan jalan usaha tani dan pembangunan irigasi yang telah rusak maupun belum dibangun secara baik agar petani dapat lebih baik dan maksimal lagi dalam usaha pertanian mereka.

3. Bagi petani di Jorong Piruko Utara hendaknya mengikuti arahan dari petugas pertanian misalnya 2 kali menanam padi dan 1 kali menanam jagung agar dapat mengembalikan unsur hara dalam tanah, mengurangi zat besi dalam tanah, mengurangi hama, serta agar dapat menjaga budaya gotong royong dan memberikan lapangan pekerjaan untuk anggota gotong royong yang rata-rata anggotanya adalah ibu rumah tangga agar menambah penghasilan keluarga petani.

\section{DAFTAR PUSTAKA}

Badan Penyuluhan Pertanian (BPP) 2014

Sudy, Ferdinan, Edy. 2015. Dampak Penggunaan Teknologi Pertanian Terhadap Sistem Budaya Sosial Masyarakat Tani Desa Mareda Kaleda Kecamatan Mawewa Timur Kabupaten Sumba Barat Daya Provinsi Nusa Tenggara Timur. Skripsi: Fakultas Ilmu Sosial dan Ilmu Komunikasi Universitas Kristen Satya Wacana. 
Hernanto, Fadholi, 1991. Ilmu Usaha tani. Surabaya: Penebar Swadaya.

Mangunwidjaja. Djumali. 2005. Pengantar Teknologi Pertanian. Jakarta: Penebar Swadaya.

Mosher, A.T., 1985.Menggerakkan dan Membangun Pertanian. Jakarta: Yasaguna

Mardikanto, T. 1993. Penyuluhan Pembangunan Pertanian. Surakarta: Sebelas Maret Univercity Press.

Nasution, M. 2003. Konsumsi Pangan Hewani dan Status Gizi Siswa SD Negeri 105349, Lubuk Pakam Deli Serdang. Pendidikan Science. Vol. 27, No. 3. Medan.

Soetriono,dkk. 2006. Pengantar Ilmu Pertanian. Malang: Bayumedia Publishing. 